\title{
Identification of sources of resistance of Passiflora rootstocks to fusariosis in areas with disease outbreaks in Mato Grosso state, Brazil
}

\author{
Dulândula Silva Miguel-Wruck ${ }^{1}$, Givanildo Roncatto ${ }^{2}$, Maurel Behling ${ }^{3}$, \\ Valeria de Oliveira Faleiro ${ }^{4}$, Solange Maria Bonaldo ${ }^{5}$, Flávio Dessaune Tardin 6 \\ Abstract - The aim of the study was to identify sources of resistance of Passiflora rootstocks to \\ Fusarium sp. in two experimental areas with histories of disease foci in Mato Grosso state, Brazil. \\ The experiment was carried out from June 2012 to December 2015 and was of randomized block \\ design with eight treatments in which susceptible cultivar $P$. edulis was grafted onto hybrids CPAC \\ MJ-H-87, CPAC MJ-H-76, CPAC MJ-H-86 and CPAC MJ-H-88, the commercial cultivar and native \\ $P$. edulis, $P$. nitida and $P$. alata. Mortality rates of grafted plants were evaluated up to 640 days after \\ transplantation. All Fusarium sp. isolates were identified as F. oxysporum f. sp. passiflorae. Plant \\ mortality occurred earlier in the clay area than in the area with sandy clay loam. Grafted plants \\ involving $P$. edulis as rootstocks were highly susceptible to Fusarium sp. with overall mortality \\ rates above $56.25 \%$ considering both soil types, while plants with CPAC MJ-H-76 or native $P$. nitida \\ rootstocks were more resistant with mortality rates below $12.5 \%$. Grafted plants with CPAC MJ-H- \\ 86 as rootstock were highly resistant in clay soil but highly susceptible in soil with high proportion \\ of sand. Only grafted plants involving CPAC MJ-H-76 as rootstock showed moderate resistance. \\ Index Terms: Passiflora sp., Fusarium oxysporum f. sp. passiflorae, grafting, fusariosis resistance.

\section{Identificação de fontes de resistência de porta-enxertos de Passiflora à fusariose em áreas com focos da doença em Mato Grosso, Brasil}

Corresponding author: dulandula.wruck@embrapa.br

Received: December 09, 2020 Accepted: May 17, 2021

Copyright: All the contents of this journal, except where otherwise noted, is licensed under a Creative Commons Attribution License.
Resumo - O objetivo do estudo foi identificar fontes de resistência de porta-enxertos de Passiflora ao Fusarium sp. em duas áreas experimentais, com registro de focos da doença em Mato Grosso, Brasil. O experimento foi conduzido de junho de 2012 a dezembro de 2015 e delineado em formato de blocos casualizados com oito tratamentos, nos quais a cultivar suscetível Passiflora edulis (copa) foi enxertada nos híbridos CPAC MJ-H-87, CPAC MJ-H-76, CPAC MJ-H-86 e CPAC MJ-H-88, na própria cultivar comercial e nas espécies nativas $P$. edulis, $P$. nitida e $P$. alata. As taxas de mortalidade das plantas enxertadas foram avaliadas até 640 dias após o transplante. Todos os isolados de Fusarium sp. foram identificados como $F$. oxysporum f. sp. passiflorae. A mortalidade ocorreu mais cedo na área com solo argiloso do que naquele argilo-arenoso. Plantas enxertadas com $P$. edulis foram altamente suscetíveis ao Fusarium sp. com taxas de mortalidade superior a 56,25\%, considerando ambos os tipos de solo, enquanto plantas enxertadas com CPAC MJ-H-76 ou P. nitida foram mais resistentes com taxas de mortalidade inferiores a $12,5 \%$. Plantas enxertadas com CPAC MJ-H- 86 foram altamente resistentes em solo argiloso, mas altamente suscetíveis em solo com alta proporção de areia. Somente plantas enxertadas com CPAC MJ-H-76 mostraram ter resistência moderada.

Termos para Indexação: Passiflora sp., Fusarium oxysporum f. sp. passiflorae, enxerto, resistência à fusariose. 


\section{Introduction}

Passiflora is the largest genus in the family Passifloraceae and most of its members are native to tropical regions of the American continent. The genus comprises more than 500 species, some 70 of which produce edible passion fruit, and more than a dozen are grown commercially in various countries in the world for food or ornamental purposes (FALEIRO et al., 2017). Owing to the rich biodiversity of the genus, various species have been targeted by breeding programs for genetic improvement and for expanding existing production systems (FALEIRO et al., 2019a).

In Brazil, the most cultivated species is Passiflora edulis Sims. (known locally as maracujá-azedo or maracujá-amarelo), although commercialization of cultivars of $P$. alata Curtis (maracujá-doce), P. setacea DC. (maracujá-do-cerrado) and P. cincinnata Mast. (maracujá-da-caatinga) has been approved by the Brazilian Ministry of Agriculture, Livestock and Food Supply (MACHADO et al., 2017; RONCATTO et al., 2011). Nevertheless, $P$. edulis represents more than $95 \%$ of the national production intended for consumption in natura and for agroindustry. Even though Brazil is one of the world's leading producers of passion fruit, with some 41,800 ha under cultivation yielding $593,429 \mathrm{t}$ of fruit in 2019 (IBGE, 2020), production is confined mainly to small-scale family-based units and is, therefore, of considerable socioeconomic importance to the country (FALEIRO et al., 2016).

Passion fruit orchards are vulnerable to various diseases including fusariosis and collar rot caused by soil-borne Fusarium spp., particularly Fusarium solani and $F$. oxysporum f. sp. passiflorae, that can reduce significantly the useful productive life of orchards and bring about substantial economic losses (SILVA et al., 2017; MACHADO et al., 2015). In the semiarid region of Brazil, Fusarium sp. can cause 70 to $100 \%$ mortality of passion fruit plants within a short period of time and, in some cases, even before an orchard has become productive (SÃO JOSÉ et al., 2011).

The control of Fusarium wilt is difficult not only because of the lack of efficient agrochemicals, but also because the pathogen can survive in the soil without a host for extended periods of time (MACHADO et al., 2015; MELETTI, 2011; FISCHER et al., 2005). The fungus enters through the rhizome via natural or artificial wounds including those caused by agricultural implements and phytonematodes such as Meloidogyne incognita and Rotylenchulus reniformis (GARCIA et al., 2007). Thus, symptoms such superficial root rot and/or the presence of lesions at the plant collar serve to distinguish Fusarium wilt from other diseases (MACHADO et al., 2015). As infection spreads up into the stems and leaves, water flow is restricted causing wilting and yellowing of the foliage and eventually plant death.
Fusariosis occurs initially as localized outbreaks of disease deriving from contaminated seeds and seedlings or the remains of infected crops and fruits, and spreads rapidly to neighboring plants through direct contact with the roots or by water present in the soil (MELETTI, 2011; SÃO JOSÉ et al., 2011). In the absence of efficient chemical control, the only alternatives for preventing the spread of Fusarium wilt are the adoption of appropriate management practices and the introduction of genetic resistance by developing resistant cultivars or by grafting onto resistant rootstocks (HURTADO-SALAZAR et al., 2015; MACHADO et al., 2015; MORGADO et al., 2015). Commercial cultivars of passion fruit present low genetic variability with regards to disease-resistance. Species of Passiflora that are native to Brazil represent valuable resources for genetic improvement owing to their rich biodiversity and, in many cases, compatibility with $P$. edulis (JUNQUEIRA et al., 2005). Reports are available concerning the yields, under commercial conditions, of $P$. edulis grafted onto native passion fruit species as rootstocks including, for example, $P$. phoenicea Lindl. (syn. P. alata) in Rio de Janeiro state, $P$. nitida Kunth and P. alata in Mato Grosso state, P. gibertii N.E. Br. in Bahia state and $P$. foetida L. in Rio Grande do Norte state (MACHADO et al., 2015; PREISIGKE et al., 2015; CAVICHIOLI et al., 2011a,b).

In the municipality of Terra Nova do Norte, Mato Grosso, Fusarium wilt was detected for the first time in 2005 (ARAUJO et al., 2012) and has now spread to 50 out of the 160 ha planted with P. edulis. There is, therefore, an urgent need for action to control the disease in the region, and the most plausible solution is the use of grafting techniques (AMBROSIO et al., 2018; SEMPREBOM et al., 2012). Considering that properly characterized and registered Fusarium-resistant rootstocks are currently unavailable (FALEIRO et al., 2019b), the aim of the present study was to identify sources of resistance of Passiflora rootstocks to Fusarium sp. in two experimental areas with histories of disease foci in Mato Grosso state, Brazil.

\section{Material and Methods}

The experiments were performed between June 2012 and December 2015 in two private farms situated in the municipality of Terra Nova do Norte, Mato Grosso, located about $150 \mathrm{~km}$ from the major regional town of Sinop. Both farm A (-55.103 W, -10.537 S; 292 m altitude) and farm B (-55.126 W, $-10.575 \mathrm{~S} ; 307 \mathrm{~m}$ altitude) had related occurrence of $F$. oxysporum f. sp. passiflorae. According to the Secretaria de Estado de Planejamento e Coordenação Geral do Mato Grosso (2011) the local soil is classified as Dystrophic Typic Hapludults clay (area A) and sandy clay loam (area B). 
The experiment was of randomized block design and involved eight treatments with four repetitions each of four plants, totalizing 16 plants per treatment. The treatments comprised the commercial cultivar $P$. edulis 'BRS Gigante Amarelo' (control) as scion with the hybrids CPAC MJ-H-87 (Passiflora alata Curtis. $\mathrm{x}$ Passiflora maliformis L.), CPAC MJ-H-76 'BRS Gigante Amarelo’ x (Passiflora quadrifaria Vanderpl. x Passiflora setacea DC.) x Passiflora incarnata L., CPAC MJ-H-86 (Passiflora setacea DC. x Passiflora coccinea Aubl. x P. speciosa Gardener) and CPAC MJ-H-88 (Passiflora katsshbachu $\mathrm{x}$ (P. vitifolia Kunth $\mathrm{x}$ P. setacea DC.), the cultivar $P$. edulis 'BRS Gigante Amarelo', and the native $P$. edulis Sims, $P$. nitida Kunth and $P$. alata Curtis.

Preparation of seedlings was carried out in the experimental nursery of Cooperativa Agrícola Mista Terra Nova Ltda (Coopernova) according to the method described by Nogueira-Filho et al. (2010). In the case of $P$. nitida Kunth, seeds were stored at $10^{\circ} \mathrm{C}$ for 6 months prior to sowing in order to break dormancy. Seeds were soaked in distilled water for $12 \mathrm{~h}$ and then sown in 72 cell polystyrene seed trays $(120 \mathrm{~mL}$ per cell) containing a mixture of light soil, fully-matured cattle manure and commercial Plantmax ${ }^{\circledR}$ substrate (peat, pine bark and vermiculite; Plantmax ${ }^{\circledR}$ Sementes) in the proportion of 3:1:1. Germinated seedlings remained under greenhouse conditions until required for grafting.

The cleft graft method with a full slit on the hypocotyl of the rootstocks (NOGUEIRA-FILHO et al., 2010) was employed in grafting seedlings that were 6 to $8 \mathrm{~cm}$ in height and with around three definitive leaves, a stage attained around 30 days after sowing for vigorous growing seedlings or 90 days for slower plants. Grafted seedlings were maintained in the nursery and irrigated daily with the aid of a micro sprinkler system until required for transplantation to the field at 30 days after grafting.

The experimental areas were laid out with $4 \mathrm{~m}$ spaces between the $0.40 \times 0.40 \times 0.40 \mathrm{~m}$ plant pits and 3 $\mathrm{m}$ spaces between the training wires that were fixed $2 \mathrm{~m}$ above ground on support posts. Prior to the commencement of experiments, the chemical and physical properties of the soil in experimental areas A and B were analyzed in $0-20 \mathrm{~cm}$ layer (Table 1) and soil acidity was corrected by liming each of the areas with dolomitic limestone $\left(2.5 \mathrm{t} \mathrm{ha}^{-1}\right)$ as well as the individual pits $\left(0.225 \mathrm{t} \mathrm{ha}^{-1}\right)$ as recommended by Lima (2009). The plant pits also received localized fertilizing with $5 \mathrm{~L}$ of chicken manure, $1.0 \mathrm{~kg}$ of superphosphate, $200 \mathrm{~g}$ of limestone, $200 \mathrm{~g}$ of gypsum and $100 \mathrm{~g}$ of monoammonium phosphate to provide a nutrient pool as recommended by Borges (2004). Grafted seedlings were transferred to the prepared pits on $24^{\text {th }}$ July 2012 and the vines were direct to grow up towards the support wires with the aid of string lines. Standard cultural management, including drip irrigation, was carried out throughout the experimental period.
Vegetative growth was determined by measuring stem diameter $(\mathrm{cm})$ above the grafting point using a digital caliper at 90 days after planting (DAP) during the juvenile stage of the grafted plants. The mean diameter values of the grafted plants in the eight different treatments were compared using Scott-Knott test at 5\% significance. The survival and mortality rates (\%) were determined by collecting the plants that had died at 10 evaluation times, namely, 60, 120, 266, 320, 330, 360, 440, 520, 600 and 640 days after planting (DAP). The responses of the scion-rootstocks combinations to Fusarium wilt were categorized as proposed in Table 2. Samples of dead plants that had root lesions were transferred to the Laboratory of Phytopathology at the Universidade Federal de Mato Grosso (UFMT) for isolation and identification of the genus of the disease-causing fungus.

In order to identify the species of Fusarium present in fungal isolates, DNA profiling was performed in the Phytopathology Laboratory at Embrapa Agrossilvipastoril. Briefly, mycelia of fungal isolates were diluted with Milli-Q water, spread onto water agar medium and incubated at $25^{\circ} \mathrm{C}$ for $24 \mathrm{~h}$ under a $12 \mathrm{~h}$ photoperiod. Single spores were selected with the aid of a hand lens, transferred to potato dextrose agar (PDA) medium and incubated under the conditions described above for 5 days. Monosporic colonies were subcultived onto new plates containing PDA medium in order to eliminate any contaminants and maintained in a biochemical oxygen demand incubator under the conditions described above for approximately 7 days, enough time for the fungus to cover the culture medium. 
Table 1. Chemical and physical attributes of the soil (0 - $20 \mathrm{~cm}$ layer) in experimental areas A and B located in Terra Nova do Norte, Mato Grosso, Brazil

\begin{tabular}{|c|c|c|c|c|c|c|c|c|c|c|c|c|c|c|c|}
\hline \multirow{3}{*}{ Area } & \multicolumn{11}{|c|}{ Chemical composition } & \multicolumn{4}{|c|}{$\begin{array}{c}\text { Granulometry and } \\
\text { organic matter }\end{array}$} \\
\hline & \multicolumn{2}{|c|}{ pH } & $\mathbf{C a}$ & Mg & Al & $\mathbf{H}$ & & $\mathbf{P}$ & SB & CEC & BS & Sand & Silt & Clay & OM \\
\hline & $\mathrm{H}_{2} \mathrm{O}$ & $\mathrm{CaCl}_{2}$ & & $(\mathrm{~cm}$ & $\left.\mathrm{dm}^{-3}\right)$ & & $\left(\mathrm{m}_{\mathrm{s}}\right.$ & & $(\mathrm{cmo}$ & $\left.\mathrm{dm}^{-3}\right)$ & $(\%)$ & & $\left(\mathrm{g} \mathrm{kg}^{-1}\right)$ & & $\left(\mathrm{g} \mathrm{dm}^{-3}\right)$ \\
\hline A & 5.8 & 5.1 & 1.9 & 0.8 & 0.0 & 2.9 & 45 & 3.3 & 2.8 & 5.7 & 49.4 & 390 & 153 & 457 & 18.9 \\
\hline B & 5.6 & 4.8 & 1.6 & 0.5 & 0.0 & 3.3 & 62 & 3.9 & 2.3 & 5.6 & 41.1 & 625 & 84 & 291 & 22.0 \\
\hline
\end{tabular}

$\mathrm{SB}$, sum-of-bases; CEC, cation exchange capacity; BS, base saturation; OM, organic matter

Table 2. Classification of passion fruit rootstocks according to resistance to fusariosis (F. oxysporum f. sp. passiflorae) on the basis of mortality rate as proposed in this study

\begin{tabular}{|c|c|}
\hline Mortality rates $(\%)$ & Classification \\
\hline 0 & resistant \\
\hline $1.1-12.5$ & moderately resistant \\
\hline $12.6-25.0$ & moderately susceptible \\
\hline $25.1-50.0$ & susceptible \\
\hline$>50.0$ & highly susceptible \\
\hline
\end{tabular}

DNA was extracted according to the method described by Raeder and Broda (1985) and the integrity of extracted DNA evaluated by $1.5 \%$ agarose gel electrophoresis and quantitative assessment using a NanoDrop ${ }^{\mathrm{TM}}$ spectrophotometer (Thermo Fisher Scientific, Waltham, MA, USA). Polymerase chain reaction (PCR) was performed using a PCR thermal cycler (Bio-Rad, T100, Hercules, CA, USA) and the fungi-specific primer pairs ITS1-F (5'TCCGTAGGTGAACCTGCGG3') and ITS4A-R (5'TCCTCCGCTTATTGATAT-GC3') (WHITE et al., 1990). The reaction mixture contained $2.5 \mu \mathrm{L}$ of 10 $\mathrm{X}$ reaction buffer, $2.0 \mu \mathrm{L}$ of $\mathrm{MgCl}_{2}(25 \mathrm{mM}), 0.5 \mu \mathrm{L}$ of dNTP mixture $(10 \mathrm{mM}), 1.5 \mu \mathrm{L}$ each of the forward and reverse primers $(10 \mu \mathrm{M}), 1 \mu \mathrm{L}$ of Taq DNA polymerase $(5 \mathrm{U} / \mu \mathrm{L}), 100 \mathrm{ng}$ of DNA template and deionized water to a final volume of $25 \mu \mathrm{L}$. The amplification procedure involved an initial denaturation at $94{ }^{\circ} \mathrm{C}$ for $5 \mathrm{~min}$, annealing at $55^{\circ} \mathrm{C}$ for $30 \mathrm{~s}$ and extension at $72{ }^{\circ} \mathrm{C}$ for $30 \mathrm{~s}$, followed by 35 cycles of denaturation at $94{ }^{\circ} \mathrm{C}$ for $30 \mathrm{~s}$, annealing at $55^{\circ} \mathrm{C}$ for $30 \mathrm{~s}$ and extension at $72{ }^{\circ} \mathrm{C}$ for $30 \mathrm{~s}$, with a final extension step at $72{ }^{\circ} \mathrm{C}$ for $10 \mathrm{~min}$. The PCR products of each sample were submitted to $1 \%$ agarose gel electrophoresis together with a $50-700$ bp DNA ladder to detect the expected $600 \mathrm{bp}$ fragment. PCR products were purified by suspension in $100 \%$ isopropanol and centrifugation at 9,000 rpm for $15 \mathrm{~min}$, followed by suspension of the pellet in $70 \%$ ethanol and centrifugation under the same conditions. After complete evaporation of the $70 \%$ ethanol, the pellet was resuspended in $20 \mu \mathrm{L}$ of sterile distilled water and dispatched to Myleus Biotecnologia (Belo Horizonte, MG, Brazil) for sequencing.
Three composite soil samples containing $500 \mathrm{~g}$ of soil and $50 \mathrm{~g}$ of roots were taken from each experimental area in March 2013 for analysis of nematodes. The samples were placed in plastic bags, labeled and transported to the Laboratory of Nematology at Embrapa Agrossilvipastoril for extraction and identification of nematodes.

\section{Results and Discussion}

The scion (P. edulis 'BRS Gigante Amarelo') was compatible with all tested rootstocks during the experimental period as shown by the growth of the grafted plants (Table 3) despite the occurrence of disease. Some of the scion-rootstock combinations had a higher longevity than the control plants in which scion and rootstock originated exclusively from $P$. edulis 'BRS Gigante Amarelo'. 
Table 3. Mean diameter values of commercial cultivar Passiflora edulis 'BRS Gigante Amarelo' grafted onto various rootstocks and grown in two different experimental areas in Terra Nova do Norte, Mato Grosso, Brazil.

\begin{tabular}{|c|c|c|}
\hline \multirow[t]{2}{*}{ Rootstocks } & \multicolumn{2}{|c|}{$\begin{array}{l}\text { Diameter above } \\
\text { the grafting point }(\mathrm{cm})^{1}\end{array}$} \\
\hline & Area A & Area B \\
\hline Hybrid CPAC M5-H-87 (P. alata $\times$ P. maliformis) & $13.8 \mathrm{a}$ & $14.6 \mathrm{a}$ \\
\hline $\begin{array}{l}\text { Hybrid CPAC MJ-H-76 ['BRS Gigante Amarelo’x x (P. quadrifaria x P. setacea) x } \\
\text { P. incarnata] }\end{array}$ & $14.2 \mathrm{a}$ & $11.6 \mathrm{a}$ \\
\hline Hybrid CPAC MJ-H-86 [P. setacea $\mathrm{x}$ (P. coccinea $\times$ P. speciosa $)]$ & $12.3 \mathrm{a}$ & $11.4 \mathrm{a}$ \\
\hline Hybrid CPAC MJ-H-88 [P. katsshbachu $\times(P$. vitifolia $\times$ P. setacea $)]$ & $15.4 \mathrm{a}$ & $14.9 \mathrm{a}$ \\
\hline Commercial cultivar P. edulis 'BRS Gigante Amarelo' (control) & $16.0 \mathrm{a}$ & $14.1 \mathrm{a}$ \\
\hline Native $P$. edulis & $18.6 \mathrm{a}$ & $14.8 \mathrm{a}$ \\
\hline Native $P$. nitida & $12.4 \mathrm{a}$ & $11.2 \mathrm{a}$ \\
\hline Native $P$. alata & $13.1 \mathrm{a}$ & $10.9 \mathrm{a}$ \\
\hline Mean & 14.5 & 12.9 \\
\hline Coefficient of variance $(\%)$ & 18.1 & 22.6 \\
\hline
\end{tabular}

${ }^{1}$ Mean values followed by dissimilar lowercase letters in the column are significantly different according to the Scoot-Knott test at $5 \%$ significance

The isolates of Fusarium sp. collected from experimental areas $\mathrm{A}$ and $\mathrm{B}$ were all identified as $F$. oxysporum f. sp. passiflorae. The mortality of plants occurred earlier in the clay area A (39\% sand) in comparison with area $\mathrm{B}$ with a higher proportion of sand $(63 \%)$ in the $0-20 \mathrm{~cm}$ layer (Table 1). However, plant mortality occurred more abruptly and at a considerably higher rate in area $\mathrm{B}$ (Figure 1a and $1 \mathrm{~b}$ ).

Since P. edulis 'BRS Gigante Amarelo' and native $P$. edulis are highly susceptible to Fusarium wilt, the finding that grafts involving these rootstocks had overall mortality rates (considering both areas) of over $56 \%$ was expected (Table 4). Grafted plants with hybrids CPAC M5H-87 and CPAC MJ-H-88 as rootstock were moderately susceptible in area A and susceptible in area B. The overall mortality rates of plants with CPAC MJ-H-76 and $P$. nitida as rootstocks were even lower $(\leq 12.5 \%)$, thus being considered moderately resistant, indicating that the hybrid and the native species probably presented a certain source of resistance to fusariosis.

P. alata was moderately resistant in area A and susceptible in area B. Interestingly, grafted plants with hybrid CPAC MJ-H-86 as rootstock exhibited somewhat discrepant results since they were resistant in area A but highly susceptible in area B (62.5\% mortality). Hence, the moderately resistant CPAC MJ-H-76, P. nitida and $P$. alata, along with the potentially resistant cultivar CPAC MJ-H-86, constitute promising rootstocks for improving the resistance of $P$. edulis 'BRS Gigante Amarelo' to attack by Fusarium sp.
The differences in susceptibilities between grafted plants grown in the two experimental areas could be attributed to various intrinsic and environmental factors. The occurrence of intra-species or intra-cultivar variation and the extent of such genetic variability in the rootstocks could account for the differences, and this factor needs to be investigated further in order to improve Fusarium-resistance traits. The occurrence of variation between seeds could also be a contributing factor since each rootstock was derived from a single seed. In this study, the dissimilar soil texture accentuated differences in susceptibility to Fusarium sp. since area B was sandier than area A (Table 1). Sandy soils favor fungal dissemination (FISCHER; REZENDE, 2016), while clay soils suppress fungal disease. Languasco et al. (2000) observed that the incidence of Fusarium wilt in melon was higher in sandy soils compared with clay soils owing to the increase in pathogen population. Similar result was reported by Rodrigues et al. (1998), i.e. the severity of Fusarium wilt in tomatoes grown in sandy soil was higher than in clay soils. Fusarium solani is another species that occurs in passion fruit, although it is more common in clay soils with poor drainage, mainly when rainwater or irrigation water accumulates around the plants (FALEIRO; JUNQUEIRA, 2016). 

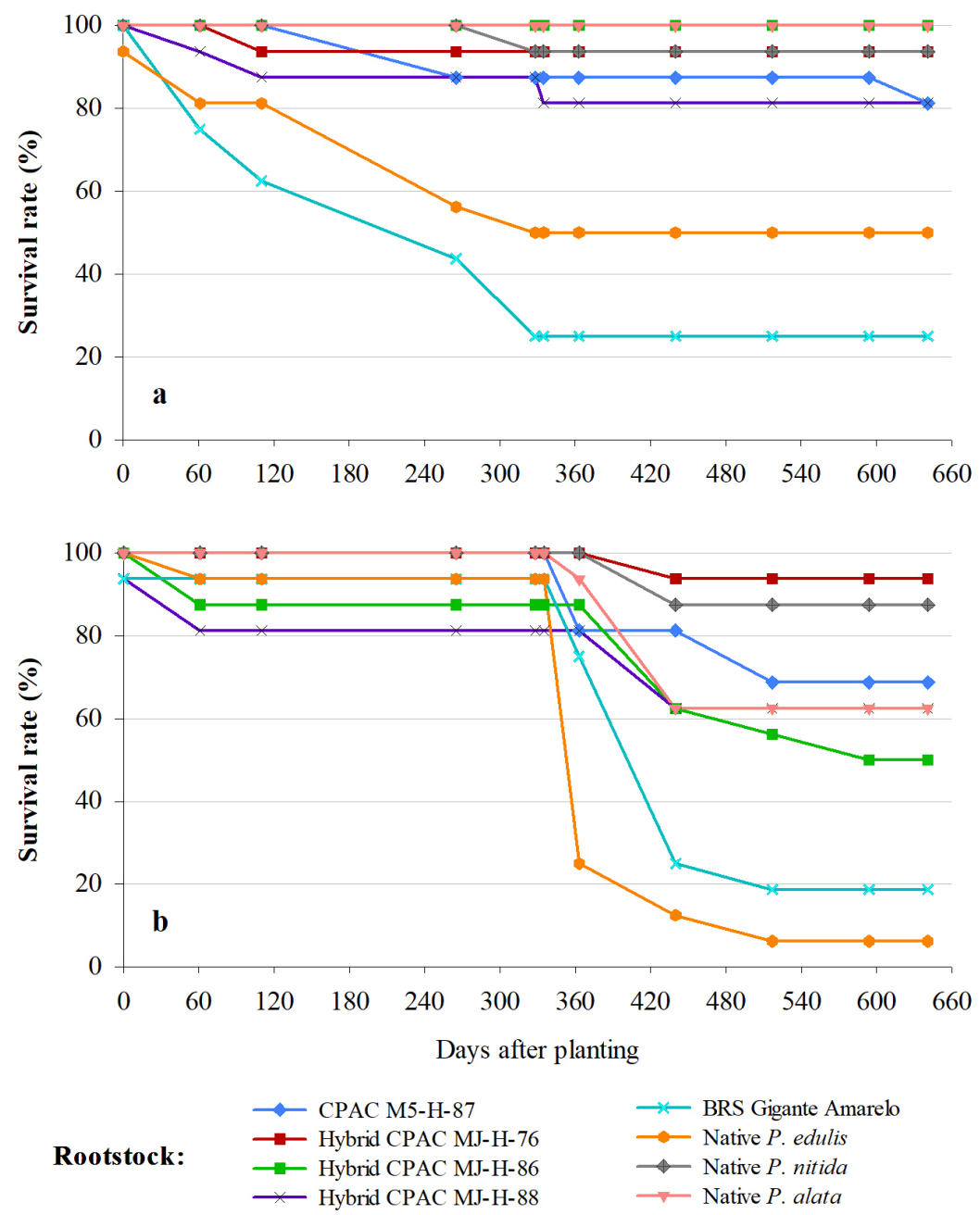

Figure 1. Survival rates (\%) in area A (a) and B (b) of cultivar Passiflora edulis 'BRS Gigante Amarelo' grafted onto different rootstocks.

The mycelia or spores of Fusarium sp. penetrate the plant roots, advance through the root cortex into the sap stream and are transported upwards. Eventually the spores and the mycelia clog the vascular vessels preventing the plant from taking up and translocating nutrients. Disruption of the transport of xylem sap towards the aerial parts and phloem sap towards the sugar sinks leads to a decrease in plant turgidity. This situation is aggravated in sandy soils because the availability of water in such soils is lower than in predominantly clay soils, so that water and nutrients become even more limited under these circumstances (KRAMER; BOYER, 1995).

An additional factor relates to the different densities of phytonematodes detected in the two experimental areas. In area $\mathrm{B}$, the two major nematodes of Passiflora cultures, namely $R$. reniformis and Meloidogyne spp., together with the pathogenic nematode Helicotylenchus dihystera, were identified, whereas only the reniform nematode was detected in area A and at low densities. Although many species of nematodes have been associated with passion fruit, members of the genera Rotylenchulus and Meloidogyne are predominantly responsible for reduced longevity, decreased productivity and economic losses (GARCIA et al., 2007). Considering the above, it is likely that the sandy soil and the high nematode density in experimental area B contributed to the increased susceptibility of grafted plants. 


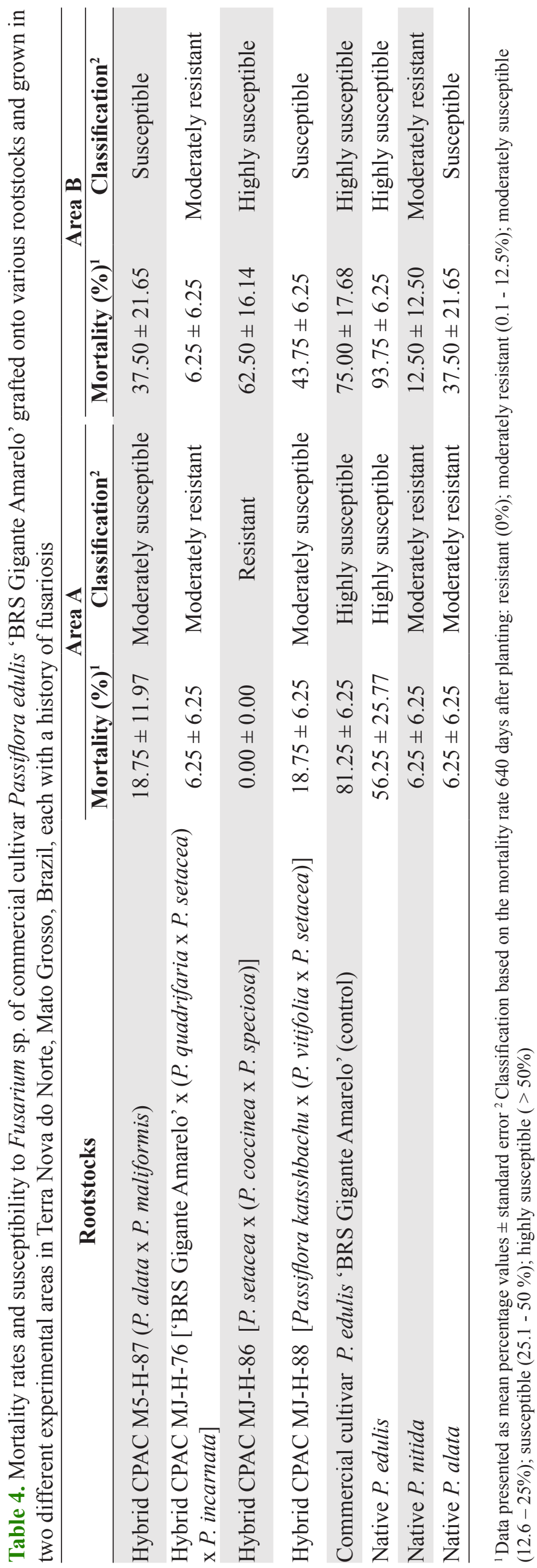

\section{Conclusions}

Of the four rootstocks observed to confer any source of Fusarium sp. resistance to the commercial cultivar $P$. edulis 'BRS Gigante Amarelo', only grafts employing the hybrid CPAC MJ-H-76 showed some source of resistance in both experimental areas and resulted in comparable mortality rates. Grafted plants employing hybrid CPAC MJ-H-86 exhibited some resistance to F. oxysporum f. sp. passiflorae when grown in predominantly clay soil but were highly susceptibility in soil containing higher levels of sand. The influence of soil properties and structure on the susceptibility of the commercial passion fruit cultivar requires further investigation since the virulence of Fusarium sp. could be modulated by soil characteristics.

\section{Acknowledgements}

The authors would like to thank the Fundação de Apoio à Pesquisa do Estado de Mato Grosso (FAPEMAT $\mathrm{n}^{\mathrm{o}}$. 751786/2011) for financial support, Coopernova for technical support and the farmers who allowed the experiments to be conducted on their properties. Additionally, we would like to express our gratitude for technical contributions to the following collegues: Laurimar Gonçalves Vendrusculo, Sílvio Tulio Spera, João Luiz Palma Meneguci, Fábio Gelape Faleiro, Nilton Tadeu Vilela Junqueira, Suzinei Silva Oliveira, Renato da Cunha Tardin Costa, Pérsio Sandir de Oliveira, Carlos Antonio Távora Araújo, Márcio Sidnei Semprebom, Daniele Caumo, Luciano Lemes do Prato, Pedro Ribeiro dos Santos, Oliveira Maciel and Luiz Gonzaga Chitarra. 


\section{References}

AMBROSIO, M.; KRAUSE, W.; SILVA, C.A., LAGE, L.A.; CAVALCANTE, N.R.; SILVA, I.V. da. Histological analysis and performance of sour passion fruit populations under different rootstocks resistant to Fusarium spp. Revista Brasileira de Fruticultura, Jaboticabal, v.40, n.1, p.274-283, 2018.

ARAUJO, C.A.T.; FALEIRO, F.G.; SEMPREBOM, M.S.; KRAUSE, W. Sobrevivência de plantas enxertadas de maracujazeiro em área com histórico de doenças causadas por Fusarium spp. no Mato Grosso. In: CONGRESSO BRASILEIRO DE FRUTICULTURA, 21., 2012. Bento Gonçalves. Anais [...]. Jaboticabal: SBF, 2012. 4p.

BORGES, A. L. Nutrição mineral, calagem e adubação. In: LIM, A.A. de A.; CUNHA, M.A.P. da (ed.). Maracujá: produção e qualidade na passicultura. Cruz das Almas: Embrapa Mandioca e Fruticultura, 2004. p.117-149.

CAVICHIOLI, J.C.; CORRÊA, L. de S.; BOLIANI, A.C.; SANTOS, P.C. dos. Desenvolvimento e produtividade do maracujazeiro-amarelo enxertado em três porta-enxertos. Revista Brasileira de Fruticultura, Jaboticabal, v.33, n.2, p.558-566, 2011a.

CAVICHIOLI, J.C.; CORRÊA, L. de S.; GARCIA, M. J. de M.; FISCHER, I. H. Desenvolvimento, produtividade e sobrevivência de maracujazeiro amarelo enxertado e cultivado em área com histórico de morte prematura de plantas. Revista Brasileira de Fruticultura, Jaboticabal, v.33, n.2, p.567-574, $2011 \mathrm{~b}$.

FALEIRO, F.G.; JUNQUEIRA, N.T.V.; COSTA, A.M. Importância socioeconômica e cultural do maracujá. In: FALEIRO, F.G.; JUNQUEIRA, N.T.V. (Ed.). Maracujá: o produtor pergunta, a Embrapa responde. Brasília, DF: Embrapa, 2016. p.15-21. (Coleção 500 perguntas, 500 respostas).

FALEIRO, F.G.; JUNQUEIRA, N.T.V.; JESUS, O.N.; COSTA, A.M.; MACHADO, C.F.; JUNQUEIRA, K.P.; ARAÚJO, F.P.; JUNGHANS, T.G. Espécies de maracujazeiro no mercado internacional. In: JUNGHANS, T.G.; JESUS, O.N. (ed.). Maracujá: do cultivo à comercialização. Brasília, DF: Embrapa, 2017. p.15-37.

FALEIRO, F.G.; OLIVEIRA, J.S.; JUNQUEIRA, N.T.V.; SANTOS, R.S. Banco de germoplasma de Passiflora $L$. 'Flor da Paixão' no portal Alelo Recursos Genéticos. Brasília, DF: Embrapa, 2019a. 86p. Disponível em: http:// ainfo.cnptia.embrapa.br/digital/bitstream/item/201049/1/ Germoplasma-alelo2019.pdf. Acesso em: 03 mar. 2020.
FALEIRO, F.G.; JUNQUEIRA, N.T.V.; JUNGHANS, T.G.; JESUS, O.N.; MIRANDA, D.; OTONI, W.C. Advances in passion fruit propagation. Revista Brasileira de Fruticultura, Jaboticabal, v. 41, n. 2, p.155, 2019 b.

FALEIRO, F.G., JUNQUEIRA, N.T.V. Maracujá coleção 500 perguntas e 500 respostas. Brasília (DF): Embrapa, 2016. 348p.

FISCHER, I.H.; REZENDE, J.A.M. Doenças do Maracujazeiro. In: AMORIM, L.; REZENDE, J.A.M; BERGAMIN FILHO, A; CAMARGO, L.E.A. (ed.). Manual de fitopatologia. 5.ed. São Paulo: Ceres, 2016. v.2, p.535-545.

FISCHER, I. H.; LOURENÇO, S. A.; MARTINS, M. C.; KIMATI, H.; AMORIM, L. Seleção de plantas resistentes e de fungicidas para o controle da podridão do colo do maracujazeiro causada por Nectria hematococca. Fitopatologia Brasileira, Brasília, DF, v.30, n.3, p.250258, 2005.

GARCIA, M.J.D.M.; ALMEIDA, A.M.; WILCKEN, S.R.S.; FISCHER, I.H.; SAMPAIO, A.L.; JESUS, A.M.; FUMIS, T. Reação de maracujazeiro amarelo 'Afruvec' e 'Maguary' a Meloidogyne spp. Arquivos do Instituto Biológico, São Paulo, 75, n.2, p.235-238. 2007.

HURTADO-SALAZAR, A.; SILVA, D.F.P.; SEDYAMA, C.S.; BRUCKNER, C.H. Caracterização física e química de frutos de maracujazeiro amarelo enxertado em espécies silvestres do gênero Passiflora cultivado em ambiente protegido. Revista Brasileira de Fruticultura, Jaboticabal, v.37, n.3, p.635-643, 2015.

IBGE - Instituto Brasileiro de Geografia e Estatística. SIDRA - Sistema IBGE de Recuperação Automática. Produção agrícola municipal de 2019: maracujá. Brasília: Ministério do Planejamento, Orçamento e Gestão, 2020. Disponível em: https://sidra.ibge.gov.br/ tabela/5457\#resultado. Acesso em: 09 out. 2020.

JUNQUEIRA, N.T.V.; BRAGA, M.F.; FALEIRO, F.G.; PEIXOTO, J.R.; BERNACI, L.C. Potencial de espécies silvestres de maracujazeiro como fonte de resistência a doenças. In: FALEIRO, F.G.; JUNQUEIRA, N.T.V.; BRAGA, M.F. (ed.). Maracujá germoplasma e melhoramento genético. Brasília (DF): Embrapa Cerrados, 2005. p.81-106. 
KRAMER, P.J.; BOYER, J.S. Soil and water. In: KRAMER, P.J.; BOYER, J.S. (ed.). Water relations of plants and soils. San Diego: Academic Press, 1995. p.84-114.

LANGUASCO, L.; GIOSUÈ, S.; ROSSI, V.; GUALAZZI, M. Influence of soil and cultural variables on Fusarium wilt of melon. OEPP/EPPO Bulletin, Paris, v.30, p.185190, 2000.

LIMA, C.A. Otimização de métodos de propagação do maracujazeiro via estaquia e enxertia. 2009. Dissertação (Mestrado em Ciências Agrárias) - Faculdade de Agronomia e Medicina Veterinária, Universidade de Brasília, Brasília, 2009.

MACHADO, C.F.; FALEIRO, F.G.; JUNQUEIRA, N.T.V.; JESUS, O.N.; ARAÚJO, F.P.; GIRARDI, E.A. A enxertia do maracujazeiro: técnica auxiliar no manejo fitossanitário de doenças do solo. Cruz das Almas: Embrapa Mandioca e Fruticultura, 2015. 15 p. Disponível em: https:// www.infoteca.cnptia.embrapa.br/infoteca/bitstream/ doc/1030105/1/CircularTecnica11625514Cristina.pdf. Acesso em: 04 out. 2019.

MACHADO, C.F.; FALEIRO, F.G.; JUNQUEIRA, N.T.V.; ARAÚJO, F.P.; COSTA, A.M.; JUNGHANS, T.G. Espécies silvestres de maracujazeiro comercializadas em pequena escala no Brasil. In: JUNGHANS, T.G.; JESUS, O.N. (ed.). Maracujá: do cultivo à comercialização. Brasília (DF): Embrapa, 2017. p.59-80.

MATO GROSSO (Estado). Secretaria de Estado de Planejamento e Coordenação Geral - SEPLAN-MT. Atlas de Mato Grosso: abordagem socioeconômico-ecológica. Cuiabá: Entrelinhas, 2011. 59p.

MELETTI, L.M.M. Avanços na cultura do maracujá no Brasil. Revista Brasileira de Fruticultura, v.33, n.esp, p.83-91, 2011. Disponível em: http://dx.doi.org/10.1590/ S0100-29452011000500012. Acesso em: 04 mar. 2021.

MORGADO, M.A.D.; BRUCKNER, C.H.; ROSADO, L.D.S.; SANTOS, C.E.M. Desenvolvimento de mudas de maracujazeiro-azedo enxertadas em espécies silvestres de Passiflora. Revista Brasileira de Fruticultura, Jaboticabal, v.37, n.2, p.471-479, 2015.

NOGUEIRA FILHO, G.C.; RONCATTO, G.; RUGGIERO, C.; OLIVEIRA, J.C.; MALHEIROS, E.B. Desenvolvimento e produção das plantas de maracujazeiroamarelo produzidas por enxertia hipocotiledonar sobre seis porta-enxertos. Revista Brasileira de Fruticultura, Jaboticabal, v.32, n.2, p.535-543, 2010.
PREISIGKE, S. C.; MARTINI, F. V.; ROSSI, A. A. B.; SERAFIM, M. E.; BARELLI, M. A. A.; LUZ, P. B.; ARAÚJO, K. L.; NEVES, L. G. Genetic variability of Passiflora spp. against collar rot disease. Australian Journal Crop Science, Lismore, v.9, p.69-74, 2015.

RAEDER, J.; BRODA, P. Rapid preparation of DNA from filamentous fungi. Applied Microbiology, Toronto, v.1, p.17-20. 1985.

RODRIGUES, F.A.; JULIATTI, F.C.; SILVA, O.A.; CORREAA, G.F.; PEIXOTO, J.R. Influência de diferentes classes de solo na severidade da murcha-de-fusário do tomateiro. Fitopatologia Brasileira, Brasília, DF, v.23, p.404-406, 1998.

RONCATTO, G.; SOARES, J.B.L.; VALENTE, J.P. Modalidades de enxertia para maracujazeiro: avaliação preliminar nas condições da Depressão Cuiabana. Revista Brasileira de Fruticultura, v.33, n.1, p.316-320, 2011.

SÃO JOSÉ, A.R.; BOMFIM, M.P.; HOJO, R.H; ANGEL, D.N; PIRES, M.M. Doenças do Maracujazeiro. In: PIRES, M.M.; JOSÉ, A.R.S.; CONCEIÇÃO, A.O. (ed.). Maracujá: avanços tecnológicos e sustentabilidade. Ilhéus: UESC. 2011. p.115 -146.

SEMPREBOM, M.S.; FALEIRO, F.G.; ARAUJO, C.A.T.; PRADO, L.L.; HADDAD, F.; JUNQUEIRA, N.T.V. Tecnologia de mudas enxertadas de maracujazeiro azedo para controle de doenças causadas por Fusarium spp. no Mato Grosso - a experiência da Coopernova. In: CONGRESSO BRASILEIRO DE FRUTICULTURA, 22., 2012, Bento Gonçalves. Anais [...]. Jaboticabal: SBF, 2012. Disponível em: https://ainfo.cnptia.embrapa. br/digital/bitstream/item/73336/1/TECNOLOGIA-DEMUDAS-ENXERTADAS-DE-MARACUJAZEIRO4ZPE.pdf. Acesso em: 04 abr. 2015.

SILVA, R.M.; AMBRÓSIO, M.M.Q.; AGUIAR, A.V.M.; FALEIRO, F.G.; CARDOSO, A.M.S.; MENDONÇA, V. Reação de cultivares de maracujazeiro em áreas com fusariose. Summa Phytopathologica, Botucatu, v.43, n.2, p.98-102, 2017.

WHITE, T.J.; BRUNS, T.; LEE, S.; TAYLOR, J. Amplification and direct sequencing of fungal ribosomal RNA genes for phylogenetic. In: GELFALD, D.H.; SNISNSKY, J.J.; HITE, T.J (org.). PCR protocols: a guide to methods and applications. San Diego: Academic Press, 1990. p.315-322. 